\title{
EVALUATION OF DRUG-DRUG INTERACTIONS AMONG DEN- TAL PRESCRIPTIONS AT DIFFERENT CLINICAL SETTINGS OF SIALKOT, PUNJAB, PAKISTAN.
}

1. BDS, MSc Oral Pathology Assistant Professor

Department of Oral Pathology Islam Dental College Sialkot.

2. BDS, MSc Oral Biology

Associate Professor and HOD Department of Oral Biology, Islam Dental College, Sialkot.

3. MD, FCPS

Assistant Professor

Department of Oral and Maxillofacial Surgery

Islam Dental College Sialkot.

4. BDS, MSc

Assistant Professor

Department of Operative Dentistry Isra Medical and Dental College,

5. Pharm.D, PhD.

Assistant Professor

Faculty of Pharmacy,

University of Sindh, Jamshoro.

6. M.Phil.

Lecturer

Faculty of Pharmacy

Ziauddin University Karachi.

Correspondence Address:

Dr. Danish Javed

Department of Oral Pathology

Islam Dental College Sialkot.

sciencepk62@gmail.com

Article received on:

22/11/2018

Accepted for publication:

09/02/2019

Received after proof reading:

22/05/2019

\begin{abstract}
Danish Javed', Sana Zafar², Shakeel Ahmed ${ }^{3}$, Khurram Anwar ${ }^{4}$, Mudassar Iqbal Arain ${ }^{5}$,
\end{abstract} Saira Shahnaz ${ }^{6}$

ABSTRACT: Drug plays a fundamental role in disease prevention and ultimately promotes healthy society. Inappropriate prescribing traditions are not only goes toward useless \& unsafe treatment but also prolongation of illness and distress the patient and increased economic burden. This study can also be helped as a pharmaco-epidemiological extent for carrying out of a national preventive drug policy. To assess Drug-Drug interactions among dental prescriptions at different clinical settings of Sialkot, Punjab, Pakistan. Study Design: A descriptive observational study. Settings: A hospital based study was conducted in different clinical settings of Sialkot, Punjab, Pakistan. Period: Six months from January to June 2018 according to study criteria. Materials and Methods: The Sample size is 500 prescriptions were collected randomly in six months from January to June 2018 according to study criteria. A structured data form was used for collecting demographics, diagnosis, complications, present medications prescribed for each patient and find out number of prescriptions which shows drug-drug interactions and level of severity as well. MS Excel and descriptive statistics was used for find out the result of the study. Results: The current study finding shows that males have more prevalence i.e. $55.8 \%$ of dental problems compared to females (44.2\%). Mostly patients were included in 51-60 age group (30.2\%). 50.2\% patients have pervious medication history and most common diagnosis was acute periapical infection (26.8\%). Further mostly analgesics $(26 \%)$ were prescribed followed by antibiotics (21.5\%) with elevated body temperature (29.4\%). Commonly six drugs per prescription prescribed (34.2\%) least numbers of drugs prescribed per prescription is $2(8.2 \%)$. $30.6 \%$ prescriptions reported with drug-drug interaction in which $26.8 \%$ were prescribed in acute periapical infections. More frequently was observed between Glimepiride - Levofloxacin (25.5\%) followed by levofloxacin-prednisolone (24.8\%). Conclusion: It was concluded that the frequency of drug-drug interactions in prescriptions by dentist in private dental clinics of Sialkot is high but majority of drug interactions with other drugs were found to be of significant minor occurring at pharmacodynamics level.

Key words: $\quad$ Dental, Drug, Interaction, Pakistan, Prescriptions, Sialkot.

Article Citation: Javed D, Zafar S, Ahmed S, Anwar K, Arain MI, Shahnaz S. Evaluation of drug-drug interactions among dental prescriptions at different clinical settings of Sialkot, Punjab, Pakistan. Professional Med J 2019; 26(6):859864.DOI: 10.29309/TPMJ/2019.26.05.1387

\section{INTRODUCTION}

Drug plays a fundamental role in disease prevention and ultimately promotes healthy society. Inappropriate prescribing traditions are not only goes toward useless and unsafe treatment but also prolongation of illness and distress the patient and increased economic burden. Thus, irrational use of medicines distresses the quality and safety of beneficial care. Unreasonable multiple drugs prescriptions known as polypharmacy may be due to management based on sign and symptoms rather than the proper diagnosis. Such type of polypharmacy may lead to decline in quality of drug utilization, waste of resources, rise of bacterial resistance, increased economic burden, increased adverse drug reactions, and drug drugs interactions. ${ }^{1}$ Therefore, evaluation of drugdrug interactions are considered a necessary starting in forming an effective drug utilization stewardship program, with the leading objectives of upgrade the efficacy of treatment \& reducing the microbial resistance; this study can also be helped as a pharmaco-epidemiological extent for 
carrying out of a national preventive drug policy. ${ }^{2}$ Systematic drug use have discovered current measures by incorporating the consequences of studies signifying active preventive programs and decreased miss use of drug. ${ }^{3}$ The rational practice of prescribing is imperious in dental care, hence, a survey was conducted to evaluate the drugs prescription trends in primary dental care in Sialkot, to determine prescribing patterns, to recognise ultimate misuses or overuse of medicines and to assist the standards for the rational use of drugs. The aim of this study was to analyse clinical prescriptions record of dental patients attending private clinics of Sialkot. This was to evaluate the prescribing trends of different drugs and investigate drug-drug interactions which are prescribed in a prescription.

It is no surprise that the possibility for drug-drug and adverse drug interactions are a growing fear for all stages of patient health care system as well as in dental medicine, the additional complications are common food products such as grapefruit juice, which are used by many patients because of it has benefits for cardiovascular and cancerpreventing, it has been complicated in some of serious drug interactions. ${ }^{4}$ polypharmacy in prescriptions is common and is well known reason in dental facilitate to increase number of drug-drug interactions (DDIs), multiple number of drugs prescribing usually surges the possibility of interaction between the drugs. The causes which greatly contribute in adverse interactions include: diet, polypharmacy, patient's age and those having heart problems \& other co-morbid. ${ }^{6,7}$

While most commonly prescribed drugs (analgesics, aesthesia / vasoconstrictors\& antibiotics) by the dentist, its show many of the possible interactions which can take place with other drugs. A main point to be here is that most of these drug interactions have been arose when the patients have been using drugs for prolonged periods of time and misuse it. In specifically, the consequences of combining supra therapeutic doses of local aesthetics along with narcotic sedative has been disturbed the patients. Hence dentists should be aware and alert to these adverse interactions and recognise the reasons on which they mostly occur, in order to evaluate the risk posed by wrong drug prescribing to patients who are already used medication for other diseases. ${ }^{5}$ The aim of this study was to analyze clinical prescriptions record of dental patients attending private clinics of Sialkot. This was to evaluate the prescribing trends of different drugs and investigate adverse drug interactions of drug which are prescribed in a prescription.

\section{METHODOLOGY Study Design}

A hospital based descriptive observational study.

\section{Study Site}

The study was conducted in the different clinical settings of Sialkot, Punjab, Pakistan.

\section{Study Sample}

Sample size is 500 prescriptions were collected randomly in six months (Jan-Jun 2018) according to study criteria.

\section{Collection of Data}

500 prescription were collected and a data form was used for collecting data. This form contains various portions such as demographics, diagnosis, complications, present medications prescribed for each patient and find out number of prescriptions which show drug-drug interactions. The information were recorded in the prepared data form.

\section{Data Analysis}

MS Excel and descriptive statistics was used for find out the result of the study.

\section{RESULTS}

\section{Gender Wise Distribution}

Table-I demonstrates that males have more prevalence $55.8 \%$ to dental problems as compared to females (44.2\%).

\begin{tabular}{|l|c|c|}
\hline \multicolumn{1}{|c|}{ Gender } & No. of Patients & Percentage \\
\hline Male & 279 & $55.8 \%$ \\
\hline Female & 221 & $44.2 \%$ \\
\hline Total & 500 & $100 \%$ \\
\hline & Table-l. Gender wise distribution \\
\hline
\end{tabular}




\section{Age Wise Distribution}

Mostly patients were included in 51-60 age group (30.2\%).

\begin{tabular}{|l|c|c|}
\hline \multicolumn{1}{|c|}{ Age Groups } & No. of Patients & Percentage \\
\hline Less than 10 years & 31 & $6.2 \%$ \\
\hline $11-20$ & 55 & $11 \%$ \\
\hline $21-30$ & 43 & $8.6 \%$ \\
\hline $31-40$ & 57 & $11.4 \%$ \\
\hline $41-50$ & 62 & $12.4 \%$ \\
\hline $51-60$ & 151 & $30.2 \%$ \\
\hline$>61$ & 101 & $20.2 \%$ \\
\hline Total & 500 & $100 \%$ \\
\hline & &
\end{tabular}

\section{Pervious Medical History of Patients}

Majority of the prescriptions have not any Information about medical history (40\%).

\begin{tabular}{|l|c|c|}
\hline Medical History & No. of Patients & Percentage \\
\hline Yes & 251 & $50.2 \%$ \\
\hline No & 49 & $9.8 \%$ \\
\hline Not mentioned & 200 & $40 \%$ \\
\hline Total & 500 & $100 \%$ \\
\hline \multicolumn{2}{|c|}{ Table-III. Pervious medical history of patients } \\
\hline
\end{tabular}

Frequency of Co-morbidity with Dental Problems

Most frequent co-morbid disease is hypertension $(11.2 \%)$ followed by diabetes (10.2\%).

\begin{tabular}{|l|c|c|}
\hline \multicolumn{1}{|c|}{ Diseases } & $\begin{array}{c}\text { No. of } \\
\text { Patients (500) }\end{array}$ & $\begin{array}{c}\text { Percentage } \\
\text { (100\%) }\end{array}$ \\
\hline Diabetes & 51 & $10.2 \%$ \\
\hline Hypertension & 56 & $11.2 \%$ \\
\hline Congestive Heart Failure & 23 & $115 \%$ \\
\hline Myocardial Infarction & 18 & $3.6 \%$ \\
\hline \multicolumn{2}{|c|}{ Table-IV. Frequency of co-morbidity wit dental } \\
problems
\end{tabular}

\section{Most Frequently Diagnosed Dental Problems} Mostly patients reported with acute periapical infection (17.4\%) followed by Pulpitis (15.6\%).

\begin{tabular}{|l|c|c|}
\hline \multicolumn{1}{|c|}{ Clinical Diagnosis } & $\begin{array}{c}\text { No. of } \\
\text { Patients }\end{array}$ & Percentage \\
\hline Acute periapical infection & 87 & $17.4 \%$ \\
\hline Pulpitis & 78 & $15.6 \%$ \\
\hline Chronic periodontitis & 79 & $15.8 \%$ \\
\hline $\begin{array}{l}\text { Periapical or periodontal } \\
\text { abscess }\end{array}$ & 76 & $15.2 \%$ \\
\hline Acute inflammation & 61 & $12.2 \%$ \\
\hline Dry socket & 23 & $4.6 \%$ \\
\hline Implant placement & 35 & $7 \%$ \\
\hline $\begin{array}{l}\text { Inflammation of the } \\
\text { sublingual gland }\end{array}$ & 34 & $6.8 \%$ \\
\hline Fracture of teeth & 27 & $5.4 \%$ \\
\hline Total & 500 & $100 \%$ \\
\hline \multicolumn{2}{|c|}{ Table-V. Diagnoses frequency } \\
\end{tabular}

\section{Frequency of Various Clinical Symptoms}

Mostly Elevated temperature and systemic spread (29.4\%) was reported in patients.

\begin{tabular}{|l|c|c|}
\hline \multicolumn{1}{|c|}{ Clinical Symptoms } & $\begin{array}{c}\text { No. of } \\
\text { Patients }\end{array}$ & Percentage \\
\hline $\begin{array}{l}\text { Elevated temperature and } \\
\text { systemic spread }\end{array}$ & 147 & $29.4 \%$ \\
\hline Localized fluctuant swelling & 120 & $24 \%$ \\
\hline Gross/diffuse swelling & 98 & $19.6 \%$ \\
\hline Restricted mouth opening & 70 & $24 \%$ \\
\hline Difficulty in swallowing & 65 & $13 \%$ \\
\hline Total & 500 & $100 \%$ \\
\hline
\end{tabular}

Table-VI. Reported various clinical symptoms

\section{Number of Drugs Prescribed in Per Prescription} Drug-drug was mostly reported in Patients to whom four to six medicines (34.2\%) were prescribed.

\begin{tabular}{|l|c|c|}
\hline No. of Drugs & $\begin{array}{c}\text { No. of } \\
\text { Prescriptions }\end{array}$ & Percentage \\
\hline 2 & 41 & $8.2 \%$ \\
\hline 3 & 44 & $8.8 \%$ \\
\hline 4 & 73 & $14.6 \%$ \\
\hline 5 & 87 & $17.4 \%$ \\
\hline 6 & 171 & $34.2 \%$ \\
\hline$>6$ & 84 & $16.8 \%$ \\
\hline Total & 500 & $100 \%$ \\
\hline & Table-VII. Number of drugs prescribed in per \\
& \multicolumn{2}{|c|}{ prescription } \\
\hline
\end{tabular}


Prescribing frequency of different drug categories

The drugs which dentists use in daily practice can be divided into few groups: analgesics, local anesthetics, antimicrobials (Antibiotics, Antifungals, Antivirals), antifungals and antiseptics. Most frequently analgesics (26\%) were prescribed.

\begin{tabular}{|l|c|c|}
\hline Name of Category & No of Drug & Percentage \\
\hline Antibiotics & 551 & $21.5 \%$ \\
\hline Analgesics & 667 & $26 \%$ \\
\hline Anesthetics & 472 & $18.4 \%$ \\
\hline Antifungals & 331 & $12.9 \%$ \\
\hline Antiseptics & 263 & $10.3 \%$ \\
\hline Miscellaneous Drugs & 278 & $10.9 \%$ \\
\hline Total & 2562 & $100 \%$ \\
\hline
\end{tabular}

Table-VIII. Prescribing frequency of different drug categories

\section{Frequency of Prescription with Drug-Drug Interaction}

$30.6 \%$ patients prescription were showed that their prescribing drugs can interact to each other.

\begin{tabular}{|l|c|c|}
\hline \multicolumn{1}{|c|}{ Case } & $\begin{array}{c}\text { No. of } \\
\text { Prescription }\end{array}$ & Percentage \\
\hline Drug-drug interaction & 153 & $30.6 \%$ \\
\hline Appropriate & 347 & $69.4 \%$ \\
\hline Total & 500 & $100 \%$ \\
\hline
\end{tabular}

Table-IX. Frequency of prescription with drug-drug interaction

Frequencies of Drug-Drug Interact in Different Diagnosis

Out of $153,26.8 \%$ patients with acute periapical infection were reported.

\section{Frequencies of Reported Drug-Drug Interactions}

Out of 500 hundred, in 153 prescriptions drug - drug interactions were reported. This Table enlists widespread interaction, Glimepiride Levofloxacin $(25.5 \%)$ was the most prevalent interacting pair.

\begin{tabular}{|c|c|c|c|c|}
\hline \multicolumn{2}{|c|}{ Clinical Diagnosis } & \multicolumn{2}{|c|}{$\begin{array}{c}\text { No of } \\
\text { Prescriptions }\end{array}$} & Percentage \\
\hline \multicolumn{2}{|c|}{$\begin{array}{l}\text { Acute periapical } \\
\text { infection }\end{array}$} & \multicolumn{2}{|l|}{41} & $26.8 \%$ \\
\hline \multicolumn{2}{|c|}{ Pulpitis } & \multicolumn{2}{|l|}{29} & $19 \%$ \\
\hline \multicolumn{2}{|c|}{$\begin{array}{l}\text { Inflammation of the } \\
\text { sublingual gland }\end{array}$} & \multicolumn{2}{|l|}{24} & $15.7 \%$ \\
\hline \multicolumn{2}{|c|}{$\begin{array}{l}\text { Periapical or periodontal } \\
\text { abscess }\end{array}$} & \multicolumn{2}{|l|}{21} & $13.7 \%$ \\
\hline \multicolumn{2}{|c|}{ Fracture of teeth } & \multicolumn{2}{|l|}{12} & $7.9 \%$ \\
\hline \multicolumn{2}{|c|}{ Chronic periodontitis } & \multicolumn{2}{|l|}{16} & $10.4 \%$ \\
\hline \multicolumn{2}{|c|}{ Dry socket } & \multicolumn{2}{|l|}{7} & $4.6 \%$ \\
\hline \multicolumn{2}{|c|}{ Implant placement } & \multicolumn{2}{|l|}{3} & $1.9 \%$ \\
\hline \multicolumn{2}{|c|}{ Total } & \multicolumn{2}{|l|}{153} & $100 \%$ \\
\hline \multicolumn{5}{|c|}{$\begin{array}{c}\text { Table-X. Frequencies of drug-drug interact in different } \\
\text { diagnosis }\end{array}$} \\
\hline Drugs Name & $\begin{array}{l}\text { No. of } \\
\text { Prescrip- } \\
\text { tion }\end{array}$ & $\begin{array}{l}\text { Perce- } \\
\text { ntage }\end{array}$ & \multicolumn{2}{|r|}{$\begin{array}{l}\text { Potential } \\
\text { Adverse } \\
\text { Outcomes }\end{array}$} \\
\hline $\begin{array}{l}\text { Ibuprofen - } \\
\text { Levofloxacin }\end{array}$ & 14 & $9.2 \%$ & Seiz & zures \\
\hline $\begin{array}{l}\text { Ciprofloxacin } \\
\text { - Diclofenac }\end{array}$ & 27 & $17.6 \%$ & \multicolumn{2}{|c|}{$\begin{array}{l}\text { Increased } \\
\text { ciprofloxacin } \\
\text { plasma } \\
\text { concentrations }\end{array}$} \\
\hline $\begin{array}{l}\text { Aspirin - } \\
\text { Atenolol }\end{array}$ & 19 & $12.4 \%$ & \multicolumn{2}{|c|}{$\begin{array}{l}\text { Decreased } \\
\text { antihypertensive } \\
\text { effect }\end{array}$} \\
\hline $\begin{array}{l}\text { Diclofenac - } \\
\text { Metronidazole }\end{array}$ & 16 & $10.5 \%$ & \multicolumn{2}{|c|}{$\begin{array}{l}\text { Increased } \\
\text { exposure of } \\
\text { diclofenac }\end{array}$} \\
\hline $\begin{array}{l}\text { Glimepiride - } \\
\text { Levofloxacin }\end{array}$ & 39 & $25.5 \%$ & $\begin{array}{l}\text { Hyp } \\
\text { hyp }\end{array}$ & $\begin{array}{l}\text { Doglycemia or } \\
\text { erglycemia }\end{array}$ \\
\hline $\begin{array}{l}\text { Levofloxacin - } \\
\text { Prednisolone }\end{array}$ & 38 & $24.8 \%$ & Ten & don rupture \\
\hline Total & 153 & $100 \%$ & & \\
\hline Table-XI. & $\begin{array}{r}\text { equencies } \\
\text { intera }\end{array}$ & $\begin{array}{l}\text { s of reporte } \\
\text { actions: }\end{array}$ & & ug-drug \\
\hline
\end{tabular}

\section{DISCUSSION}

Right selection of drug is basic requirement for rational use of medicines in dentistry. ${ }^{8}$ Drug interactions are major problem and a common factor of adverse effects, Outcomes from the adverse reactions for about 10 to 20 percentage of patients' admissions to the hospital moreover $1 \%$ hospital admissions result from drug-drug interactions. ${ }^{9}$ An unpredicted change is significant interaction in patient occur as a result of inappropriate therapeutic drugs combination. Around about 3 to $5 \%$ of all adverse 
reactions of drugs may outcomes from drugdrug interactions. ${ }^{10}$ In this study, Prescriptions of 500 patients from different dental clinics were collected, in which 153 patients have to prescribe with those drugs which can interact to each other. Most commonly 6 drug were prescribed in $34.2 \%$ patients, which show polypharmacy trend in prescribing. Acute periapical infection are mostly reported in dental patients $(26.6 \%)$ and common symptom was Elevated temperature and systemic spread (29.4\%). The possibilities of adverse drug reactions increase in the existence of pervious medical history, comorbidities, and polypharmacy. Most frequently prescribed drug categories were analgesics (26\%) and antibiotics (21.5\%) because postoperative dental pain and infection are common problems in these patients. Analgesics and antibiotics mostly show drug-drug interactions in dentistry. Nonsteroidal anti-inflammatory drugs (NSAIDs) are mostly prescribed by dentist as analgesics for pain management. These NSAIDS can inhibit cyclooxygenase-1 (COX-1) \& (COX-2) enzymes, which are implicated in the production of thromboxane's and prostaglandins (PG) thus, the drugs which are reliant on the activity and physiologic levels of these intermediaries may be overstated when NSAIDS are used with them. ${ }^{11}$ Mostly drug interaction was observed in Glimepiride - Levofloxacin $25.5 \%$ followed by levofloxacin oral and prednisolone oral (25\%) [Combination of this may be increase risk of tendon rupture. Among them, majority of the interactions were of moderate and minor.

\section{CONCLUSION}

The frequency of drug-drug interactions in prescriptions by dentist private dental clinics of Sialkot is high but majority of drug interactions with other drugs were found to be of significant minor occurring at pharmacodynamics level. NSAID group interaction with other drugs was more common. Implementation rational prescribing guidelines and knowledge can reduces the chances of drug-drug interactions in dental practice.

Copyright@ 09 Feb, 2019.

\section{REFERENCES}

1. Trostle J. Inappropriate distribution of medicines by professionals in developing countries. Soc Sci Med, 1996; 42: 1117-1120. 2.

2. Tawfik Y, Northrup R, Prysor-Jones S. Utilizing the potential of formal and informal private practitioners in child survival: situation analysis and summary of promising interventions. Bureau for Africa, office of sustainable development. (2002).

3. Mertens-Talcott SU, Zadezensky I, De Castro WV, Derendorf H, Butterweck V. Grapefruit-drug interactions: Can interactions with drugs be avoided? J Clin Pharmacol 2006: 46: 1390-1416.

4. Offerhaus O. Rational use of drugs in Balkans: A WHO Workshop. Essential Drugs Monitor. 1995: L20 (3):38-42.

5. Haas DA. Adverse drug interactions in dental practice: Interactions associated with analgesics. Part III in a series. J Am Dent Assosc. 1999; 130:397407.

6. Kaliamurthy K, Kumar A, Punniyakotti S, Devanandan $P$. Study of Drug-Drug interactions in general medicine department of a Tertiary Care Hospital. J Appl Pharm Sci. 2015; 5(12):122-124. doi: 10.7324/ JAPS.2015.501221.

7. Costa AJ. Potential drug interactions in an ambulatory geriatric population. Fam Pract. 1991; 8:234-236.

8. Offerhaus O. Rational use of drugs in Balkans: A WHO Workshop. Essential Drugs Monitor. 1995:L20 (3):38-42.

9. Jankel CA, Fitterman LK. Epidemiology of drug-drug interactions as a cause of hospital admissions. Drug Saf. 1993; 9(1):51-59.

10. Adverse Drug Reactions and Drug-Drug Interactions: Consequences and Costs-By: AMFS Pharmacology Expert. Available from: http://www.amfs.com/ resources/ medical-legal-articles-by-our experts/350/ adverse-drugreactions-and-drug-drug-interactionsconsequences-andcosts. Accessed on March 2017.

11. Haas DA. Adverse drug interactions in dental practice: Interactions associated with analgesics. Part III in a series. J Am Dent Assosc. 1999; 130:397407. 


\begin{tabular}{|c|c|c|c|}
\hline \multicolumn{4}{|c|}{ AUTHORSHIP AND CONTRIBUTION DECLARATION } \\
\hline Sr. \# & Author-s Full Name & Contribution to the paper & Author $=\mathbf{s}$ Signature \\
\hline 1 & Danish Javed & Concept \& Write up. & \\
\hline 2 & Sana Zafar & Write up \& Collection of data. & \\
\hline 3 & Shakeel Ahmed & Analysis. & \\
\hline 4 & Khurram Anwar & Analysis. & \\
\hline 5 & Mudassar lqbal Arain & Write up \& Proof reading & \\
\hline 6 & Saira Shahnaz & Proof reading & \\
\hline
\end{tabular}

